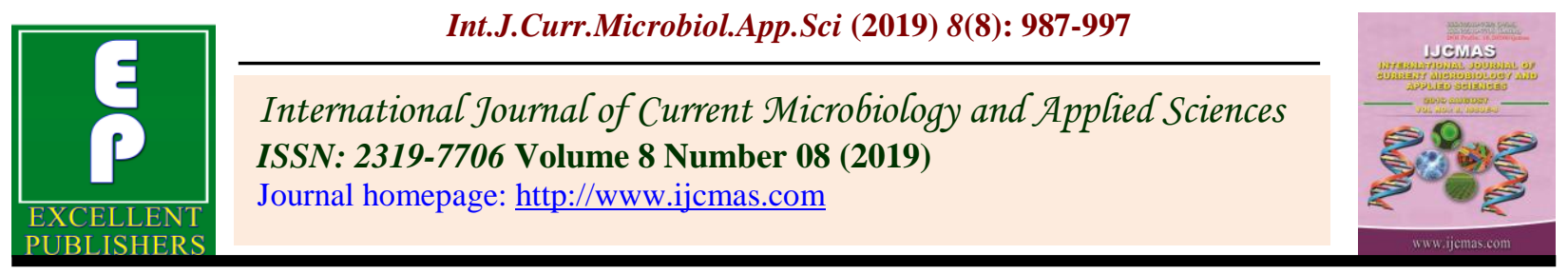

Original Research Article https://doi.org/10.20546/ijcmas.2019.808.114

\title{
Studies on Cultural and Molecular Variability among the Isolates of Sclerotium rolfsii Sacc.
}

\author{
V.R. Kulkarni* and Y.R. Hegde \\ Department of Plant Pathology, College of Agriculture, Dharwad University of Agricultural \\ Sciences, Dharwad-580005, Karnataka, India \\ *Corresponding author
}

\section{A B S T R A C T}

Sclerotium wilt/ rot of potato caused by Sclerotium rolfsii Sacc. is one of the major soil borne diseases of potato causing heavy losses every year. Ten isolates varied with respect to morphological characters. The colour of mycelium was light buff to cottony white. The

\section{Keywords}

Colony diameter, Sclerotium rolfsi, RAPD, Sclerotia

Article Info

Accepted:

10 July 2019

Available Online:

10 August 2019

sclerotial initiation started between $5^{\text {th }}$ and $9^{\text {th }}$ day in different isolates. The growth rate was excellent in DSr1, DSr2 and DSr3 isolates. The colour of sclerotia was dark brown in DSr1 and DSr3; brown in DSr2, DSr4, BSr1 and HSr1 while it was light brown in BSr3, HSr2 and HSr3. The shape of the sclerotia was spherical in all the isolates except DSr1 and BSr2 wherein ellipsoidal and subspherical shapes were noticed respectively. Highest dry mycelial weight and mean colony diameter was observed in isolate DSr3. Isolate DSr1 $(2.10 \mathrm{~mm}$ and $98.38 \mathrm{mg}$ ) recorded highest sclerotial diameter and test weight. RAPD data distinguished the ten isolates into two major clusters A and B. Cluster A was classified in to A1 and A2 further A2 was sub grouped in to A3 and A4 comprising of isolates DSr1 (UAS, Dharwad), DSr2 (Kurubagatti) and DSr3 (Hangarki) belong in to Dharwad district. A major cluster B was classified up to sub-sub cluster B6. Cluster B1 comprising of isolates of Hassan district and cluster B2 comprising of isolates of Belgaum district. In the present investigation, the results revealed that geographical locations of isolates were closely related.

\section{Introduction}

The potato (Solanum tuberosum L.) plant is a member of solanaceae or the nightshade family. Potato is one of the important and widely grown vegetables of the world, introduced in $17^{\text {th }}$ century. The mineral production in case of potato is 3.70 times more than wheat and 11 times more than rice. Potato gives more carbohydrates, fiber and vitamins per unit area and time than the other major food crops. Potato is low energy food,
$200 \mathrm{~g}$ of boiled potatoes provide about 138 Kcal of energy (Shekhawat and Dahiya, 2000). It is rich in potassium and phosphorus (Shekhawat et al., 1992). Tubers contain at least 12 essential vitamins and are a good source of vitamin ' $C$ ' containing about 14-25 $\mathrm{mg} / 10 \mathrm{~g}$ of fresh weight of tubers (Thornaton and Sieczka, 1980).

Potato wilt caused by Sclerotium rolfsii Sacc. is a well-known polyphagous, ubiquitous and a non-target pathogen. It is one of the most 
destructive soil inhabiting pathogens so far reported. It has attained a serious status in Northern Karnataka particularly in the transitional belt. It is essential to develop a suitable Integrated Disease Management (IDM) with cultural practices, organic amendments and biological management practices. In order to reduce the environmental hazards, to avoid the development of resistant strains and reduce the cost of cultivation.

\section{Materials and Methods}

\section{Morphological and cultural studies}

The following experiment was conducted to study the variation in the morphological characters of isolates of $S$. rolfsii collected from different locations. Fifteen $\mathrm{ml}$ of potato dextrose agar was poured into petriplates. Mycelial discs $(5 \mathrm{~mm})$ of seven days old culture of the respective isolates were placed at the center of the plate.

Three replications were maintained for each treatment at room temperature $\left(27 \pm 1^{\circ} \mathrm{C}\right)$ for 3 days and colony characters like, colony diameter, pigmentation and texture were recorded. To get matured sclerotial bodies the cultures were further incubated up to thirty days. Diameter of ten sclerotial bodies was recorded in each treatment with the help of screw gauge and observations were statistically analysed. The total number of sclerotia produced per $\mathrm{cm}^{2}$, weight of 100 sclerotia and shape of sclerotia of individual isolates were also recorded and data were analysed statistically.

\section{Molecular variability}

Random Amplified Polymorphic DNA (RAPD) analysis was used to detect the variations among the isolates of $S$. rolfsii. Standard protocols were used for the isolation of DNA and RAPD analysis.

\section{Stock solutions}

Extraction buffer:

50 mMTris $-\mathrm{HCl}$

$150 \mathrm{mMNaCl}$

100 mM EDTA

$10 \%$ SDS:

Dissolve $10 \mathrm{~g}$ of Sodium dodecy1 sulphate in $100 \mathrm{~m} 1$ of distilled water

\section{$5 \mathrm{M} \mathrm{NaCl}:$}

Dissolve $292 \mathrm{~g}$ of $\mathrm{NaC} 1$ in 1 liter of distilled water

$10 \%$ CTAB in $0.7 \mathrm{M} \mathrm{NaCl}$ solution

\section{Chloroform:}

Isoamyl alcohol - 24: 1

$70 \%$ ethanol:

Dilute $70 \mathrm{ml}$ of alcohol in $30 \mathrm{ml}$ of distilled water

$\mathrm{T}_{10} \mathrm{E}_{1}$ :

10 mMTris

$1 \mathrm{mM}$ EDTA

$\mathrm{pH} 8.0$

$100 \mu \mathrm{M}$ random primers

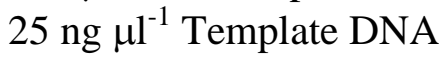

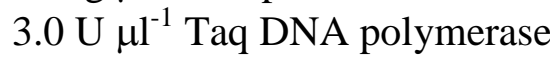

\section{Procedure}

Approximately 20-25 $\mathrm{mg}$ of ground lyophilized mycelia was placed in $1.5 \mathrm{ml}$ eppendorf tube and suspended in $500 \mu \mathrm{l}$ extraction buffer and vortexed until evenly suspended. Later $50 \mu \mathrm{l}$ of 10 per cent SDS was added and shaken gently at $37^{\circ} \mathrm{C}$ for $1 \mathrm{hr}$. Seventy five $\mu$ of $5 \mathrm{M} \mathrm{NaCl}$ was added and mixed thoroughly but gently. Sixty-five $\mu$ of 
$\mathrm{CTAB} / \mathrm{NaCl}$ was added to this solution. Mixed thoroughly and incubated at $65^{\circ} \mathrm{C}$ for 10-20 min. Equal volume $(700 \mu \mathrm{l})$ of $24: 1$ chloroform: isoamy1 was added and shouldn't be filled up to the brim. Mixed thoroughly by shaking vigorously in a shaker for 5 minutes. This was done by putting the tubes in an eppendorf tube rack and placing another eppendorf rack on top of the tubes. The two racks were secured with rubber bands and are then placed on their sides while shaking. Tube was, spinned at $10,000 \mathrm{rpm}$ for $12 \mathrm{~min}$. Transferred the aqueous, viscous supernatant to a fresh tube and 0.6 volume $(450 \mu \mathrm{l})$ cold 2 propanol was added to precipitate the nucleic acid. Kept inside $-20^{\circ} \mathrm{C}$ freezer for at least an hour. Spinned at $10,000 \mathrm{rpm}$ for $12 \mathrm{~min}$. Decanted the supernatant by using a pipettor instead of pouring because of the jelly - like consistency of the pellet. DNA pellet was washed with 70 per cent ethanol and dried completely. Two hundred $\mu 1 \mathrm{x}$ TE was added. After the DNA was completely dissolved, $2 \mu \mathrm{l}$ $(1 / 100$ vol.) of RNase A $(10 \mathrm{mg} / \mathrm{ml})$ was added. Mixed and incubated at room temperature for 10 to $15 \mathrm{~min}$. Precipitated DNA by adding $2 \mathrm{x}$ volume $(400 \mu \mathrm{l})$ absolute ethanol. Mixed and placed at $20^{\circ} \mathrm{C}$ for 30 minutes. Spinned at $10,000 \mathrm{rpm}$ for $12 \mathrm{~min}$. Supernatant was decanted and pellet was washed with 70 per cent ethanol and dried completely. Dissolved in $200 \mu \mathrm{l} \mathrm{TE}$.

\section{Random primers}

Commercial kit OPA, OPB and OPF of decamer DNA primers were obtained from integrated DNA technologies supplied by Sigma Industrial and Laboratory Equipments Inc., Bangalore, India.

\section{dNTPs}

The four individual dNTPs such as dATP, dGTP, dCTP and dTTP were obtained form M/S Bangalore Genei Pvt. Ltd. Bangalore

\section{Taq DNA polymerase}

Taq DNA polymerase and 10x Taq buffer were obtained from M/S Bangalore Genei Pvt. Ltd., Bangalore.

\section{Thermocycler}

Corbett Research Gradient PCR supplied by JH BIO Innovation Pvt. Ltd., Bangalore was used for cyclic amplification of DNA.

\section{The thermoprofile for PCR}

The PCR amplification for RAPD analysis was performed according to Williams et al., (1990) with certain modifications. The optimum conditions for DNA amplifications used were depicted in Table 1.

After the completion of the PCR, the products were stored at $4^{0} \mathrm{C}$ until the gel electrophoresis was done.

A total of 20 primers with the following sequences were used in the study as shown in the Table 2.

\section{Master mix for PCR}

Amplification reaction mixture was prepared in $0.2 \mathrm{ml}$ thin walled PCR tubes containing following components. The total volume of each reaction mixture was $20 \mu \mathrm{l}$. The following reaction mixture was found to be optimum for PCR amplification.

$10 \mathrm{x}$ assay buffer with $15 \mathrm{mM} \mathrm{MgCl}_{2}-2.5 \mu \mathrm{l}$

dNTPs mix (2.5 mM each) - $1.0 \mu \mathrm{l}$

Primer $(5 \mathrm{pM} / \mu \mathrm{l})-1.0 \mu \mathrm{l}$

Template DNA $(25 \mathrm{ng} / \mu \mathrm{l})-1.0 \mu \mathrm{l}$

Sterile distilled water $-14.30 \mu \mathrm{l}$

Taq DNA polymerase $\left(3.0 \mathrm{U}^{-1} \mathrm{l}^{-1}\right)-0.2 \mu \mathrm{l}$

Except template, the master mix was distributed to PCR tubes $(19 \mu \mathrm{l} /$ tube $)$ and later 
$1 \mu$ of template DNA from the respective isolates was added making the final volume to $20 \mu \mathrm{l}$.

Separation of amplified products by agarose gel electrophoresis

\section{Requirements}

Electrophoretic unit: Gel casting through, gel combs, Power-pack, UV-Transilluminator

Agarose (1.2\%)

Bromophenol blue

Ethidium bromide $\left(0.5 \mathrm{~g} \mathrm{~m}^{-1}\right)$

$50 \mathrm{x}$ TAE (stock): Tris - base $-60.5 \mathrm{~g}$

Glacial acetic acid $-14.25 \mathrm{ml}$

$0.5 \mathrm{M}$ EDTA - $25 \mathrm{ml}$

Make up the volume to $250 \mathrm{ml}, \mathrm{pH} 8.0$

Working solution (1 x TAE): $20 \mathrm{ml}$ of $50 \mathrm{x}$ TAE was made upto $1000 \mathrm{ml}$ by using distilled water.

\section{Procedure}

Three grams of agarose was weighed and added to a conical flask containing $250 \mathrm{ml}$ of $1 \mathrm{x}$ TAE buffer. The agarose was melted by heating the solution in an oven and the solution was stirred to ensure even mixing and complete dissolution of agarose. The solution was then cooled to about $40-45^{\circ} \mathrm{C}$. Two to three drops of ethidium bromide $\left(0.5 \mu \mathrm{g} \mathrm{m} 1^{-1}\right)$ was added.

The solution was mixed and poured into the gel casting platform after inserting the comb. While pouring sufficient care was taken for not allowing the air bubbles to trap in the gel. The gel was allowed to solidify and the comb was removed after placing the solidified gel into the electrophoretic apparatus containing sufficient buffer (1x TAE) so as to cover the wells completely. The amplified products (20 $\mu \mathrm{l})$ to be analysed were carefully loaded into the sample wells, after adding bromophenol blue with the help of micropipette. Electrophoresis was carried out at 60 volts, until the tracking dye migrated to the end of the gel. The gel was taken out from electrophoretic apparatus and DNA bands were viewed under transilluminator and photoghraphed for documentation.

\section{Scoring the amplified fragments}

The amplified profiles for all the primers were compared with each other and the bands of DNA fragment were scored as ' 1 ' for the presence and ' 0 ' for the absence of a band generating the ' 0 ', ' 1 ' matrices.

The genetic similarity coefficient was estimated using NTSYS PC 2.0 software programme (Rohlf, 1998). The clustering was done and dendrogram were drawn by following unweighted pair group with arithmetic mean (UPGMA) routine, using the above programme other parameters computed were,

Number of polymorphic bands

Per cent polymorphism = -------------- X 100

Total number of bands

\section{Results and Discussion}

\section{Morphological and cultural studies}

The morphological characters of each isolate of $S$. rolfsii on potato dextrose agar were studied and recorded. The characters viz., radial growth, colony colour, mycelial characters, shape, size, number of sclerotial bodies $\mathrm{cm}^{-2}$ and test weight of sclerotial bodies were recorded and data are presented in table 5, 3 and 4 and plate 11 .

Ten isolates varied with respect to colony characteristics viz., growth rate, colour and shape of the colony. The mycelium was light 
buff coloured in DSr1, DSr4, BSr1 and HSr3 isolates. In the remaining isolates it was cottony white. The sclerotial initiation was observed on $5^{\text {th }}$ or $6^{\text {th }}$ day in all Dharwad isolates i.e. in DSr1, DSr2, Dsr3 and DSr4 isolates, while in Belgaum ( $\mathrm{BSr} 2$ and $\mathrm{BSr} 3$ ) isolates it was upto 9 days. Hasan isolates (HSr1, HSr2 and HSr3) took 7-8 days for the sclerotial initiation.

The growth rate was excellent in DSr1, DSr2 and DSr3. The growth rate was moderate in $\mathrm{DSr} 4, \mathrm{BSr} 1$, while it was good in remaining isolates viz., $\mathrm{BSr} 2, \mathrm{BSr} 3, \mathrm{HSr} 1, \mathrm{HSr} 2$ and HSr3. None of the isolates showed growth.

The colour of sclerotia was dark brown in DSr1 and DSr3; brown in DSr2, DSr4, BSr1 and $\mathrm{HSr} 1$ while it was light brown in BSr3, $\mathrm{HSr} 2$ and $\mathrm{HSr} 3$. The shape of the sclerotia was found spherical in all the isolates except DSr1 and $\mathrm{BSr} 2$ wherein elipsoidal and subspherical shapes were noticed respectively (Table 5).

The variation in colony diameter was recorded in all the ten isolates of Sclerotium rolfsii at different intervals of time as described in 'Material and Methods' and presented in Table 3.

The results revealed that, there was differential response among the isolates with respect to colony diameter. All the isolates recorded increased colony diameter with advancement of time interval from $24 \mathrm{~h}$ to 48 $\mathrm{h}$ and to $72 \mathrm{~h}$. The mean colony diameter was maximum in DSr3 $(57.64 \mathrm{~mm})$ which was on par with DSr1 $(57.20 \mathrm{~mm})$ and significantly superior over all other isolates, DSr2 (53.86 $\mathrm{mm}$ ) which was next best one. The isolates HSr2 (30.09 mm) and HSr1 (31.05 mm) recorded significantly least colony diameter than compared to all the treatments.

Interaction between isolates and time intervals was also significant. Isolates viz., DSr1 (90.00 mm), DSr3 (90.00 mm) and DSr2 (88.05 mm) recorded significantly superior colony diameter after $72 \mathrm{~h}$.

The dry mycelial weight of different isolates was recorded after ten days of incubation as described in 'Materials and Methods' and the results are presented in Table 4. The table revealed that, there is significant difference among isolates with respect to dry mycelial weight. Highest dry mycelial weight was recorded in isolate DSr3 (248.93 $\mathrm{mg})$ which was on par with DSr1 (243.40 mg), DSr2 (234.43 mg), but significantly superior than all other isolates. The isolate HSr1 (164.20 mg) recorded significantly lowest dry mycelial weight than other isolates except $\mathrm{HSr} 2$ (167.17 $\mathrm{mg}$ ) and HSr3 (167.10 mg) which are on par with each other.

The size of the sclerotia varied significantly in different isolates. The isolate DSr1 $(2.10 \mathrm{~mm})$ recorded significantly highest sclerotial diameter than all the isolates. DSr3 $(2.02 \mathrm{~mm})$ was next best followed by DSr2 $(1.70 \mathrm{~mm})$. The isolates $\mathrm{HSr} 3(1.34 \mathrm{~mm})$ and $\mathrm{HSr} 2$ (1.35 $\mathrm{mm})$ were significantly least than all the isolates.

Number of sclerotial bodies per $\mathrm{cm}^{2}$ was significantly different in different isolates. Isolate DSr2 (8.49) recorded significantly more number of sclerotial bodies than all other isolates, followed by DSr1 (7.64) and DSr3 (7.37). The isolate BSr3 (3.25) recorded significantly least number of sclerotial bodies than other isolates.

Significant variation with respect to number of sclerotia produced per $\mathrm{cm}^{2}$ was observed in $S$. rolfsii by Sulladmath et al., (1977), Manjappa (1979), Palaiah (2002), Prabhu (2003) and Jyothi (2006).

The isolates differed significantly with respect to test weight of sclerotial bodies. 
Significantly highest test weight was noticed in DSr1 $(98.38 \mathrm{mg})$ and followed by DSr3 (92.36 mg) and $\mathrm{DSr} 2(86.79 \mathrm{mg})$. The $\mathrm{HSr} 3$ (74.14 mg) recorded significantly least test weight (Table 14).Similar trend was reported by Jyothi (2006), the dry mycelial weight ranged between $73.30 \mathrm{mg}$ to 383.30 in different isolates of $S$. rolfsii.

Table.1 The thermoprofile for PCR

\begin{tabular}{|c|l|c|c|c|}
\hline $\begin{array}{c}\text { Sl. } \\
\text { No. }\end{array}$ & \multicolumn{1}{|c|}{ Step } & $\begin{array}{c}\text { Temperature } \\
\left({ }^{\mathbf{0}} \mathbf{C}\right)\end{array}$ & $\begin{array}{c}\text { Duration } \\
(\mathbf{m i n})\end{array}$ & $\begin{array}{c}\text { Number of } \\
\text { cycles }\end{array}$ \\
\hline $\mathbf{1}$ & Denaturation & $95^{\circ} \mathrm{C}$ & 5.0 & $\mathbf{1}$ \\
\hline $\mathbf{2}$ & Denaturation & $95^{\circ} \mathrm{C}$ & 1.0 & $\mathbf{4 0}$ \\
\hline $\mathbf{3}$ & Annealing & $36^{\circ} \mathrm{C}$ & 1.0 & \\
\hline $\mathbf{4}$ & Extension & $72^{\mathbf{0}} \mathrm{C}$ & 2.0 & $\mathbf{1}$ \\
\hline $\mathbf{5}$ & Final extension & $72^{\circ} \mathrm{C}$ & 8.0 & - \\
\hline $\mathbf{6}$ & Hold temperature & $\mathbf{4}^{\mathbf{0}} \mathrm{C}$ & - & $\mathbf{1}$ \\
\hline
\end{tabular}

Table.2 Random primers with the following sequences were used in RAPD PCR amplification

\begin{tabular}{|c|c|c|c|}
\hline Primer & Sequence & & \\
\hline OPA-01 & 5 CAG GCC CTT C-3 & OPA-11 & 5 TCG GCG ATA G-3 \\
\hline OPA-02 & 5 TGC CGA GCT G-3 & OPA-12 & 5 CAG CAC CCA C-3 \\
\hline OPA-03 & 5 AGT CAG CCA C-3 & OPA-13 & 5 TCT GTG CTG G-3 \\
\hline OPA-04 & 5 AAT CGG GCT G-3 & OPA-14 & 5 TTC CGA ACC C-3 \\
\hline OPA-05 & 5 AGG GGT CTT G-3 & OPA-15 & $\mathbf{5}$ AGC CAG CGA A-3 \\
\hline OPA-06 & 5 GGT CCC TGA C-3 & OPA-16 & 5 GAC CGC TTG T-3 \\
\hline OPA-07 & 5 GAA ACG GGT G-3 & OPA-17 & 5 AGG TGA CCG T-3 \\
\hline OPA-08 & 5 GTG ACG TAG G-3 & OPA-18 & $\mathbf{5}$ CAA ACG TCG G-3 \\
\hline OPA-09 & 5 GGG TAA CGC C-3 & OPA-19 & $\mathbf{5}$ GTT GCG ATC C-3 \\
\hline OPA-10 & $\mathbf{5}$ GTG ATC GCA G-3 & OPA-20 & $\mathbf{5}$ TCG GCG ATA G-3 \\
\hline
\end{tabular}


Table.3 Variation in the different isolates of Sclerotium rolfsii on potato dextrose agar

\begin{tabular}{|c|c|c|c|c|c|}
\hline \multirow{2}{*}{$\begin{array}{c}\text { SI. } \\
\text { No. }\end{array}$} & \multirow{2}{*}{ Isolates } & \multicolumn{4}{|c|}{ Colony diameter $(\mathbf{m m})$} \\
\cline { 3 - 6 } & & $24 \mathrm{hr}$ & $48 \mathrm{hr}$ & $72 \mathrm{hr}$ & Mean \\
\hline $\mathbf{1}$ & BSr 1 & 30.83 & 36.06 & 75.63 & $\mathbf{4 7 . 5 1}$ \\
\hline $\mathbf{2}$ & BSr 2 & 17.26 & 27.98 & 60.32 & $\mathbf{3 5 . 1 9}$ \\
\hline $\mathbf{3}$ & BSr 3 & 18.72 & 30.60 & 63.42 & $\mathbf{3 7 . 5 8}$ \\
\hline $\mathbf{4}$ & DSr 1 & 35.78 & 45.83 & 90.00 & $\mathbf{5 7 . 2 0}$ \\
\hline $\mathbf{5}$ & DSr 2 & 31.27 & 42.27 & 88.05 & $\mathbf{5 3 . 8 6}$ \\
\hline $\mathbf{6}$ & DSr 3 & 33.52 & 49.40 & 90.00 & $\mathbf{5 7 . 6 4}$ \\
\hline $\mathbf{7}$ & DSr 4 & 29.04 & 34.95 & 79.81 & $\mathbf{4 7 . 9 4}$ \\
\hline $\mathbf{8}$ & HSr 1 & 15.87 & 22.45 & 54.82 & $\mathbf{3 1 . 0 5}$ \\
\hline $\mathbf{9}$ & HSr 2 & 17.02 & 22.18 & 51.09 & $\mathbf{3 0 . 0 9}$ \\
\hline $\mathbf{1 0}$ & HSr 3 & 16.19 & 26.02 & 59.39 & $\mathbf{3 3 . 8 4}$ \\
\hline & Mean & 24.55 & 38.36 & 71.25 & \\
\hline & & Between & Between & Isolate x & \\
\hline & & isolates & time & time & \\
\hline & & & intervals & & \\
\hline & S.Em \pm & 0.62 & 0.34 & 1.07 & \\
\hline & CD at $\mathbf{1 \%}$ & $\mathbf{2 . 3 2}$ & $\mathbf{1 . 2 7}$ & $\mathbf{4 . 0 1}$ & \\
\hline
\end{tabular}

Table.4 Variation in different isolates of Sclerotium rolfsii with respect to mycelial weight and morphology of sclerotia

\begin{tabular}{|c|c|c|c|c|c|}
\hline $\begin{array}{c}\text { Sl. } \\
\text { No. }\end{array}$ & Isolate & $\begin{array}{c}\text { Dry } \\
\text { mycelial wt } \\
(\mathbf{m g})\end{array}$ & $\begin{array}{c}\text { Sclerotial size } \\
(\mathbf{m m})\end{array}$ & $\begin{array}{c}\text { No. of } \\
\text { sclerotial } \\
\text { bodies/cm }\end{array}$ & $\begin{array}{c}\text { Test weight of } \\
\text { 100 sclerotial } \\
\text { bodies (mg) }\end{array}$ \\
\hline $\mathbf{1}$ & BSr 1 & 190.40 & 1.50 & 4.34 & $\mathbf{8 1 . 7 1}$ \\
\hline $\mathbf{2}$ & BSr 2 & 181.33 & 1.44 & 6.35 & $\mathbf{8 3 . 4 0}$ \\
\hline $\mathbf{3}$ & BSr 3 & 195.43 & 1.42 & 3.25 & $\mathbf{8 0 . 7 6}$ \\
\hline $\mathbf{4}$ & DSr 1 & 243.40 & 2.10 & 7.64 & $\mathbf{9 8 . 3 8}$ \\
\hline $\mathbf{5}$ & DSr 2 & 234.43 & 1.70 & 8.49 & $\mathbf{8 6 . 7 9}$ \\
\hline $\mathbf{6}$ & DSr 3 & 248.93 & 2.02 & 7.37 & $\mathbf{9 2 . 3 6}$ \\
\hline $\mathbf{7}$ & DSr 4 & 190.67 & 1.66 & 5.60 & $\mathbf{8 3 . 3 1}$ \\
\hline $\mathbf{8}$ & HSr 1 & 164.20 & 1.42 & 4.07 & $\mathbf{7 6 . 7 2}$ \\
\hline $\mathbf{9}$ & HSr 2 & 167.17 & 1.35 & 4.60 & $\mathbf{7 8 . 2 1}$ \\
\hline $\mathbf{1 0}$ & HSr 3 & 167.10 & 1.34 & 3.90 & $\mathbf{7 4 . 1 4}$ \\
\hline & S.Em \pm & 6.91 & 0.02 & 0.07 & $\mathbf{0 . 1 3}$ \\
\hline & CD at 1\% & $\mathbf{2 8 . 1 2}$ & $\mathbf{0 . 0 7}$ & $\mathbf{0 . 2 7}$ & $\mathbf{0 . 5 3}$ \\
\hline
\end{tabular}




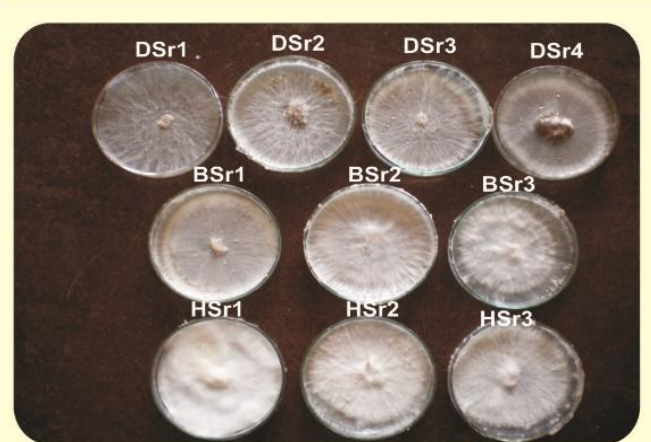

A. Solid media

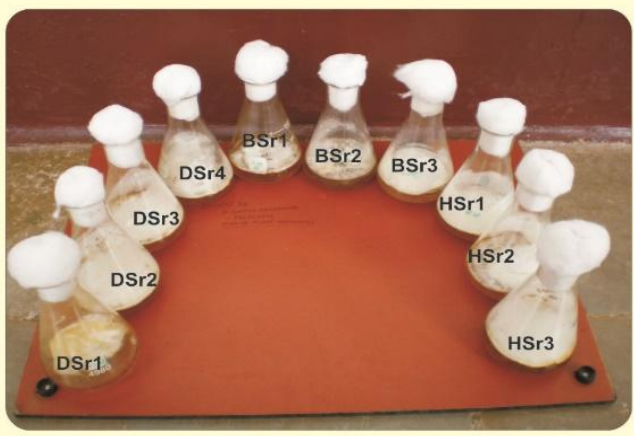

B. Liquid media

DSr1- UAS, Dharwad, campus, DSr2- Kurubagatti,

DSr3- Hangaraki, DSr4- Navalur

BSr1- Devagiri, BSr2- Kadoli, BSr3- Jafarwadi,

HSr1- Madenur farm, HSr2-Alur, HSr3- Arakalgud

Plate 11. Morphological variations in different isolates of Sclerotium rolfsii

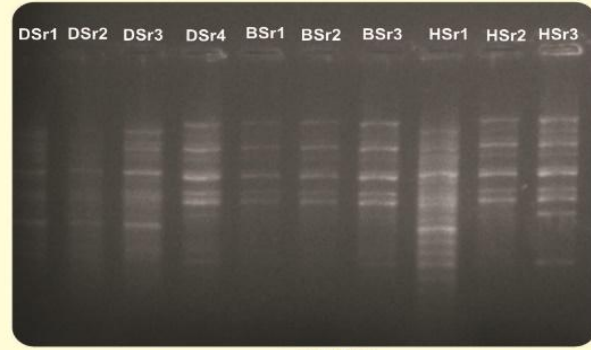

OPA2

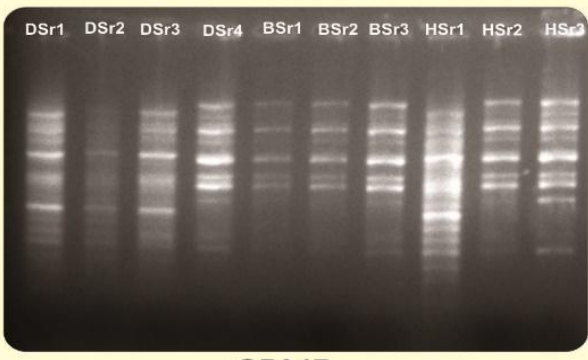

OPA17

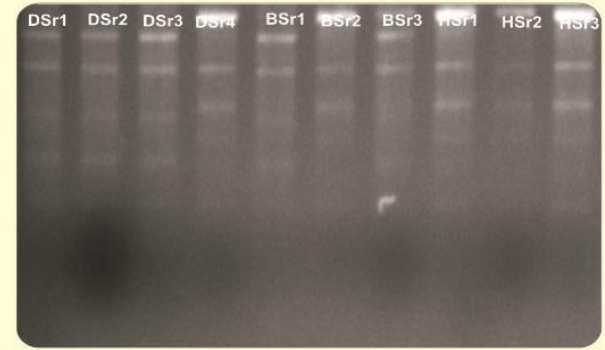

OPA8

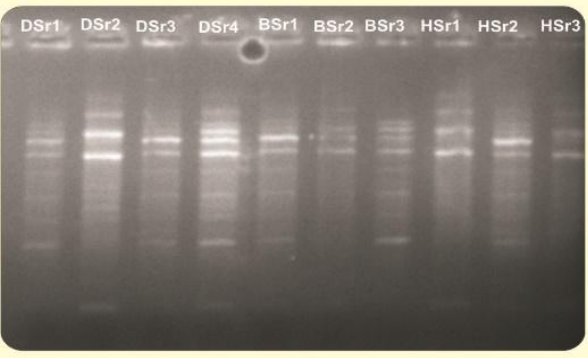

OPA18

DSr1- UAS, Dharwad, campus, DSr2- Kurubagatti,

DSr3- Hangaraki, DSr4- Navalur

BSr1- Devagiri, BSr2- Kadoli, BSr3- Jafarwadi,

HSr1- Madenur farm, HSr2- Alur, HSr3- Arakalgud

\section{Plate 12. Genetic variability in ten isolates of Sclerotium rolfsii by} RAPD method 
Table.5 Morphological characteristics of isolates of Sclerotium rolfsii on potato dextrose agar

\begin{tabular}{|c|c|c|c|c|c|}
\hline \multirow{2}{*}{$\begin{array}{l}\text { Sl. } \\
\text { No. }\end{array}$} & \multirow[t]{2}{*}{ Isolate } & \multicolumn{4}{|c|}{ Different morphological characteristics } \\
\hline & & Colony characteristics & Growth rate & Colour of sclerotia & Shape of sclerotia \\
\hline 1 & DSr 1 & Light buff coloured mycelia; slightly raised; sclerotial initiation on $6^{\text {th }}$ day & ++++ & Dark brown & Ellipsoidal \\
\hline 2 & DSr 2 & White cottony mycelium; flattened with wavy margin; sclerotial initiation on $5^{\text {th }}$ day & ++++ & Brown & Spherical \\
\hline 3 & DSr 3 & White cottony mycelium; raised colony with smooth margin; sclerotial initiation on $6^{\text {th }}$ day & ++++ & Dark brown & Spherical \\
\hline 4 & DSr 4 & Light buff coloured mycelia; flattened colony; sclerotial initiation on $5^{\text {th }}$ day & +++ & Brown & Spherical \\
\hline 5 & BSr 1 & Light buff colour colony; flattened with smooth margin; sclerotial initiation on $6^{\text {th }}$ day & +++ & Brown & Spherical \\
\hline 6 & BSr 2 & White cottony mycelium; raised colony; smooth margin sclerotial initiation on $9^{\text {th }}$ day & ++ & Brown & Subspherical \\
\hline 7 & BSr 3 & White cottony mycelium; flattened colony, smooth margin; sclerotial initiation on $9^{\text {th }}$ day & ++ & Light brown & Spherical \\
\hline 8 & HSr 1 & White cottony mycelium; flattened colony; rough margin; sclerotial initiation on $7^{\text {th }}$ day & ++ & Brown & Spherical \\
\hline 9 & HSr 2 & White cottony mycelium; slight raised colony; smooth margin; sclerotial initiation on $8^{\text {th }}$ day & ++ & Light brown & Spherical \\
\hline 10 & HSr 3 & $\begin{array}{l}\text { Light buff coloured mycelium; flattened colony; smooth margin; sclerotial initiation on } \\
7^{\text {th }} \text { day }\end{array}$ & ++ & Light brown & Spherical \\
\hline
\end{tabular}

+ Slow - Mean colony diameter of $15-45 \mathrm{~mm}$ on $3^{\text {rd }}$ day

++ Moderate - Mean colony diameter of $45-65 \mathrm{~mm}$ on $3^{\text {rd }}$ day

+++ Good - Mean colony diameter of $65-85 \mathrm{~mm}$ on $3^{\text {rd }}$ day

++++ Excellent - Mean colony diameter of $>85 \mathrm{~mm}$ on $3^{\text {rd }}$ day

Table.6 Similarity coefficient of 10 potato isolates of Sclerotium rolfsii obtained by RAPD analysis

\begin{tabular}{|l|l|l|l|l|l|l|l|l|l|l|}
\hline & DSr1 & DSr2 & DSr3 & DSr4 & BSr1 & BSr2 & BSr3 & HSr1 & HSr2 & HSr3 \\
\hline DSr1 & 1.00 & & & & & & & & & \\
\hline DSr2 & 0.58 & 1.00 & & & & & & & & \\
\hline DSr3 & 0.63 & 0.63 & 1.00 & & & & & & & \\
\hline DSr4 & 0.58 & 0.58 & 0.48 & 1.00 & & & & & & \\
\hline BSr1 & 0.52 & 0.52 & 0.59 & 0.51 & 1.00 & & & & & \\
\hline BSr2 & 0.53 & 0.61 & 0.60 & 0.61 & 0.42 & 1.00 & & & & \\
\hline BSr3 & 0.51 & 0.51 & 0.58 & 0.59 & 0.58 & 0.62 & 1.00 & & & \\
\hline HSr1 & 0.60 & 0.60 & 0.52 & 0.56 & 0.51 & 0.62 & 0.51 & 1.00 & & \\
\hline HSr2 & 0.50 & 0.50 & 0.56 & 0.50 & 0.50 & 0.53 & 0.61 & 0.61 & 1.00 & \\
\hline HSr3 & $\mathbf{0 . 4 7}$ & $\mathbf{0 . 4 7}$ & $\mathbf{0 . 6 0}$ & $\mathbf{0 . 4 7}$ & $\mathbf{0 . 5 3}$ & $\mathbf{0 . 5 4}$ & $\mathbf{0 . 5 6}$ & $\mathbf{0 . 6 2}$ & $\mathbf{0 . 6 8}$ & $\mathbf{1 . 0 0}$ \\
\hline
\end{tabular}


Similar results with respect to variation in radial mycelial growth rate were reported by several workers (Sulladmath et al., 1977; Manjappa, 1979; Mishra and Tiwari, 1990 and Palaiah, 2002).

\section{Molecular variability}

It is difficult to distinguish these species using traditional morphological differences. The suitability of random amplified polymorphic DNA (RAPD) was used to detect the variation among the isolates of $S$. rolfsii. OPA series primers were used to determine genetic distance between isolates and to construct a dendrogram.

Banding profile of different primers for ten isolates of $S$. rolfsii is given in the table 15 . Of the 20 primers used for amplification OPA1, OPA2, OPA17 and OPA 18 showed 100 per cent polymorphism (Plate 12). The OPA17 and primer did not show any amplification. Information on banding pattern for the primers was used to determine genetic distance between isolates and to construct a dendrogram (Plate 12.)

Based on simple patching coefficient, a genetic similarity was constructed to assess the genetic relatedness among the isolates of $S$. rolfsii Genetic similarity coefficient of ten isolates of $S$. rolfsii based on RAPD analysis is given in table 6 .

Similarity coefficient ranged from 0.47 to 0.68.The maximum genetic similarity of 68 per cent was between $\mathrm{HSr} 2$ and $\mathrm{HSr} 3$. Further the dendrogram constructed form the pooled data clearly showed two major clusters A and $\mathrm{B}$ at similarity coefficient of 0.54. Custer A was classified up to sub-sub cluster A4 and cluster B was classified upto 6 minor clusters comprising $\mathrm{BSr} 1, \mathrm{BSr} 3, \mathrm{BSr} 2, \mathrm{HSr} 1, \mathrm{HSr} 2$ and $\mathrm{HSr} 3$ belonging to Belgaum and Hassan district respectively.
Cluster A was sub grouped into A1 and A2 and further A2 was sub grouped in to A3 and A4 and A4 comprised of two isolates DSr1 (UAS, Dharwad) and DSr2 (Kurubagatti) belonging to Dharwad district. Similarly, B cluster was subgrouped in to B1 and B2 clusters and further B1 was sub grouped in to B3 and B4 comprising of HSr1, HSr2 and HSr3 belonging to Hassan district. The cluster B2 was sub grouped in to B5 and B6 comprising of $\mathrm{BSr} 1, \mathrm{BSr} 2$ and $\mathrm{BSR} 3$ belonging to Belgaum district. Tyson et al., (2002) studied a subset of 51 S. cepivorum Berk. Isolates and investigated for genetic diversity using universally primed PCR and random amplified polymorphic DNA analysis. Jyothi (2006) reported that a ten isolates of $S$. rolfsii were grouped in to two major clusters A and B. Major clusters A composed of isolates of wheat, chilli, cotton, groundnut, lucerne, onion, potato, soybean, sunflower and tomato. Hence, it is conformed that cluster group composed of isolates which showed very less variability.

In the present study also the results obtained showed the possibility of using RAPD technique to distinguish variability among the isolates of $S$. rolfsii. The information could then be used to determine specific primers that could be used for identification of isolates of S. rolfsii.

\section{References}

Jyothi, K.C., 2006, Morphological and molecular Variability among the isolates of Slerotium rolfsii Sacc. from different host plants. M.Sc. (Agri.) thesis, University Agricultural science. Dharwad.

Manjappa, B.M., 1979, Studies on the survival and variation in Sclerotium rolfsii Sacc. M.Sc. (Agri.) Thesis, University of Agricultural Sciences, Bangalore, P: 86. 
Mishra, M. and Tewari, S.N., 1990, Ethanolic extract toxicity of three botanicals against five fungal pathogens of rice. National Academy of Science Letters, 13: 409-412.

Palaiah, P., 2002, Studies on variability in Sclerotium rolfsii Sacc. causing stem rot of groundnut. M.Sc. (Agri.) Thesis, University of Agricultural Sciences, Dharwad.

Prabhu, H.V., 2003, Studies on collar rot of soybean caused Sclerotium rolfsii Sacc. M.Sc. (Agri.) Thesis, University of Agricultural Sciences, Dharwad, pp. 7480.

Shekhawat, G.S. and Dahiya, P.S., 2000, A neglected major food crop. In: Survey of Indian Agriculture 2000, the Hindu, Chennai, pp. 72-76.

Shekhawat, G.S., GREWAL, J.S. AND VERMA, S.C., 1992, How nutritious is the potato? Indian Farming, 42: 27-28.

Sulladmath, V.V., Hiremath, P.C. and Anilkumar, T.B., 1977, Studies on variation in Sclerotium rolfsii. Mysore Journal of Agricultural Sciences, 11: 374-380.

Tyson, J.L., Ridgway, H.J., Fullerton, R. and Stewart, A., 2002, Genetic diversity in New Zealand populations of Sclerotium cepivorum, New Zealand. Journal of Crop and Horitcultural Science Abstracts, Vol. 30, pp. 37-48.

\section{How to cite this article:}

Kulkarni, V.R. and Hegde, Y.R. 2019. Studies on Cultural and Molecular Variability among the Isolates of Sclerotium rolfsii Sacc. Int.J.Curr.Microbiol.App.Sci. 8(08): 987-997. doi: https://doi.org/10.20546/ijcmas.2019.808.114 